\title{
Kajian Potensi Rumah Nelayan Sebagai Prioritas Rumah Khusus di Kabupaten Banjar
}

\author{
Mega Ulimaz, Syahri R*, Achmad, dan Ummu Rahayu \\ Perencanaan Wilayah dan Kota, Institut Teknologi Kalimantan \\ * megaulimaz@itk.ac.id
}

\begin{tabular}{l} 
INFO ARTIKEL \\
\hline Riwayat Artikel: \\
Diterima: $2-6-2018$ \\
Disetujui: $15-7-2018$ \\
\end{tabular}

Kata Kunci:

Rumah khusus

Nelayan

Permukiman

\begin{abstract}
ABSTRAK
Abstrak: Tujuan penelitian ini adalah mengidentifikasi tingkat prioritas rumah nelayan sebagai rumah khusus di Kabupaten Banjar. Metode yang digunakan adalah deskriptif eksplorasi serta pembobotan dengan kriteria. Hasil analisa menunjukan rumah nelayan di Kecamatan AluhAluh dapat diprioritaskan sebagai rumah khusus berdasarkan dukungan kebijakan tingkat nasional dan regional, kemampuan lahan yang sesuai, ketersediaan lahan yang masih luas, isu kebutuhan dukungan kegiatan maritim yang strategis, target pengguna yang jelas yaitu nelayan yang masih bergantung pada kegiatan penangkapan ikan, serta aksesibilitas yang baik. Rumah nelayan dapat dibuat sederhana dengan ruang untuk memenuhi aktivitas nelayan.
\end{abstract}

\begin{abstract}
The purpose of this study was to identify the priority level of fisherman's houses as rumah khusus in Banjar Regency. The method is descriptive exploration and weighting by criteria. The results of the analysis show that fishermen's house in Aluh-Aluh Subdistrict can be prioritized as a special house based on national and regional policy, land capability, land availability, issues for strategic maritime activities, target users, accessibility, and fishing activities. A fisherman's house can be made simple with space to fulfill fisherman activities.
\end{abstract}

\section{A. LATAR BELAKANG}

Rumah disebut kebutuhan dasar karena merupakan unsur yang harus dipenuhi guna menjamin kelangsungan hidup manusia. Keberadaan rumah tinggal akan menentukan taraf kesejahteraan sekaligus kualitas hidup manusia karena itu suatu hunian pada hakekatnya dapat berpengaruh terhadap kualitas kehidupan penghuninya. Usaha penyediaan rumah bagi masyarakat dihadapkan pada berbagai permasalahan di antaranya terbatasnya lahan akibat perkembangan dan perubahan penggunaan lahan yang pesat. Perkembangan dan perubahan penggunaan lahan yang pesat salah satunya dipengaruhi oleh tingginya angka pertumbuhan penduduk sehingga penduduk membutuhkan lebih banyak ruang untuk beraktivitas. Dampak lain dari keterbatasan lahan adalah meningkatnya harga lahan secara signifikan sehingga biaya produksi untuk menghasilkan unit rumah juga semakin tinggi. Hal tersebut berakibat pada ketidakmampuan masyarakat dalam menjangkau harga rumah dengan penghasilan yang mereka miliki. Terdapat arahan kebijakan nasional tentang perumahan yaitu "meningkatkan akses masyarakat berpendapatan rendah terhadap hunian yang layak, aman, dan terjangkau serta didukung oleh penyediaan prasarana, sarana, dan utilitas yang memadai”. Arahan kebijakan nasional tersebut merumuskan salah satu program diantaranya pembangunan rumah khusus sejumlah 50.000 unit [1].

Perumahan dan kawasan permukiman adalah satu kesatuan sistem yang terdiri atas pembinaan, penyelenggaraan perumahan, penyelenggaraan kawasan permukiman, pemeliharaan dan perbaikan, pencegahan dan peningkatan kualitas terhadap perumahan kumuh dan permukiman kumuh, penyediaan tanah, pendanaan dan sistem pembiayaan, serta peran masyarakat. Perumahan adalah kumpulan rumah sebagai bagian dari permukiman, baik perkotaan maupun perdesaan, yang dilengkapi dengan prasarana, sarana, dan utilitas umum sebagai hasil upaya pemenuhan rumah yang layak huni. Perumahan mencakup rumah atau perumahan beserta prasarana, sarana, dan utilitas umum. Rumah didefinisikan berupa bangunan gedung yang berfungsi sebagai tempat tinggal yang layak huni, sarana pembinaan keluarga, cermin harkat dan martabat penghuninya, serta aset bagi pemiliknya [2].

Salah satu jenis rumah yang diatur dalam perundangan tersebut ialah rumah khusus, yaitu rumah yang diselenggarakan untuk memenuhi kebutuhan khusus. Rumah khusus diselenggarakan dalam rangka memenuhi kebutuhan rumah untuk kebutuhan khusus dan disediakan oleh Pemerintah dan/atau Pemerintah Daerah. Telah ditetapkan pemerima manfaat pembangunan rumah khusus, meliputi transmigran; korban bencana; lanjut usia, miskin, yatim piatu, 
dan/atau anak terlantar; masyarakat yang bertempat tinggal di pulau terluar, terpencil, atau pedalaman; masyarakat di wilayah perbatasan Negara; prajurit dan/atau petugas Negara; masyarakat nelayan; masyarakat di lokasi rawan resiko sosial; masyarakat dalam wilayah pengolah sumber daya alam; masyarakat yang terkena program pembangunan Pemerintah; masyarakat dalam kawasan cagar budaya; dan masyarakat yang memerlukan penanganan khusus [3].

Penataan permukiman nelayan pada kawasan pesisir dapat memberikan kemudahan masyarakat nelayan untuk mengakses sarana dan prasarana yang memadai [5]. Rumah khusus merupakan salah satu alternatif untuk menciptakan lingkungan kawasan permukiman nelayan dengan bantuan pemerintah sehingga nelayan dapat berfokus pada pengelolaannya saja. Rumah yang menyediakan aspek kualitas hidup harus berorientasi pada aspek ekonomi untuk menunjang kebutuhan, aspek sosial dengan karaktersitik kawasan dengan kumpulan penghuni dnegan mata pencaharian yang sama, serta memaksimalkan sumber daya lingkungan yang dimiliki [6]. Dengan demikian diperluan kajian identifikasi tingkat prioritas rumah nelayan sebagai rumah khusus di Kabupaten Banjar.

\section{B. METODE PENELITIAN}

Metode analisa yang digunakan adalah deskriptif eksplorasi serta pembobotan. Analisa deskriptif eksplorasi disertai dengan analisa kebijakan bertujuan untuk mengidentifikasi potensi rumah nelayan dalam kebijakan pembangunan dan kebijakan penataan ruang. Pembobotan menggunakan skoring merupakan teknik analisa data untuk menentukan prioritas potensi, masalah, dan kriteria penyedian rumah khusus. Penilaian merupakan nilai skala yang bersifat kontinum berdasarkan tingkat manfaat sampai dengan resiko. Jumlah nilai yang digunakan berjumlah genap dan lebih dari tiga jumlah nilai, misalnya manfaat sampai dengan resiko (nilai 3, 2, 1; tidak ada nilai o-nol) agar diperoleh kecenderungan. Hal ini terkait dengan asumsi bahwa setiap tindakan atau perlakuan terhadap suatu kondisi akan ada konsekuensi dampaknya (trade-off).

Tabel 1

Penilaian kriteria terhadap alternatif potensi rumah khusus

\begin{tabular}{|c|c|c|c|c|}
\hline Lokasi & $\begin{array}{c}\text { Kriteria } \\
\text { A: }\end{array}$ & $\begin{array}{c}\text { Kriteria } \\
\text { B: }\end{array}$ & $\begin{array}{c}\text { Kriteria } \\
\text { C: }\end{array}$ & $\begin{array}{c}\text { Kriteria } \\
\text { D: }\end{array}$ \\
\hline Lokasi 1 & 321 & 321 & 321 & $\begin{array}{lll}3 & 2 & 1\end{array}$ \\
\hline Lokasi 2 & $\begin{array}{lll}32 & 1\end{array}$ & $\begin{array}{lll}3 & 2 & 1\end{array}$ & $\begin{array}{lll}3 & 2 & 1\end{array}$ & $\begin{array}{lll}3 & 2 & 1\end{array}$ \\
\hline dst... & 321 & $\begin{array}{lll}3 & 2 & 1\end{array}$ & 321 & 321 \\
\hline
\end{tabular}

Analisa eksplorasi mendalam secara kualitatif yang mencakup kesesuaian lokasi, kondisi lingkungan site sekitar, infrastruktur, utilitas dan fasilitas publik, aksesibilitas dan transportasi, luas lahan, karakteristik tapak, kondisi dan perkembangan lingkungan sekitar, kendala pengembangan. Berikut merupakan kriteria yang digunakan dalam pembobotan.
Tabel 2.

Definisi operasional dan indikator skoring kriteria rumah khusus

\begin{tabular}{|c|c|c|c|}
\hline No & Kriteria & $\begin{array}{c}\text { Definisi } \\
\text { Operasional }\end{array}$ & Indikator \\
\hline 1 & $\begin{array}{l}\text { Dukungan } \\
\text { kebijakan }\end{array}$ & $\begin{array}{l}\text { Jumlah } \\
\text { kebijakan skala } \\
\text { nasional, } \\
\text { provinsi, dan } \\
\text { kabupaten/kota } \\
\text { yang } \\
\text { mendukung } \\
\text { pemenuhan } \\
\text { rumah khusus } \\
\text { pada target } \\
\text { penerima }\end{array}$ & $\begin{array}{l}\text { 1: Tidak ada } \\
\text { kebijakan yang } \\
\text { mendukung } \\
\text { 2: didukung oleh } 1 \\
\text { kebijakan } \\
\text { 3: didukung minimal } \\
\text { 2 kebijakan }\end{array}$ \\
\hline 2 & $\begin{array}{l}\text { Kemampuan } \\
\text { Lahan }\end{array}$ & $\begin{array}{l}\text { Tingkatan } \\
\text { kemampuan } \\
\text { dan kesesuaian } \\
\text { lahan untuk } \\
\text { pembangunan } \\
\text { permukiman }\end{array}$ & $\begin{array}{l}\text { 1: bukan merupakan } \\
\text { peruntukan } \\
\text { kemampuan lahan } \\
\text { permukiman/ } \\
\text { sberada pada } \\
\text { kawasan negative } \\
\text { list permukiman } \\
\text { 2: kemampuan } \\
\text { lahan sebagai } \\
\text { permukiman tetapi } \\
\text { memiliki } \\
\text { hambatan/pembatas } \\
\text { 3: kemampuan lahan } \\
\text { sesuai untuk } \\
\text { permukiman }\end{array}$ \\
\hline 3 & $\begin{array}{l}\text { Ketersediaan } \\
\text { Lahan }\end{array}$ & $\begin{array}{l}\text { Ketersediaan } \\
\text { lahan secara } \\
\text { administrasi } \\
\text { dan teknis } \\
\text { untuk memenuhi } \\
\text { kebutuhan } \\
\text { rumah khusus }\end{array}$ & $\begin{array}{lr}\text { 1: tidak tersedia } \\
\text { lahan untuk } \\
\text { pembangunan } \\
\text { rumah khusus } \\
\text { 2: sudah terdapat } \\
\text { lahan potensial } \\
\text { tetapi belum } \\
\text { memenuhi kriteria } \\
\text { administrasi dan } \\
\text { teknis r } \\
\text { 3: telah tesedia lahan } \\
\text { yang memenuhi } \\
\text { kriteria administasi } \\
\text { dan teknis }\end{array}$ \\
\hline 4 & $\begin{array}{l}\text { Isu dianggap } \\
\text { strategis }\end{array}$ & $\begin{array}{l}\text { Kebutuhan } \\
\text { rumah } \\
\text { diusulkan oleh } \\
\text { pemerintah } \\
\text { daerah dan } \\
\text { memerlukan } \\
\text { perencanaan } \\
\text { lebih lanjut }\end{array}$ & 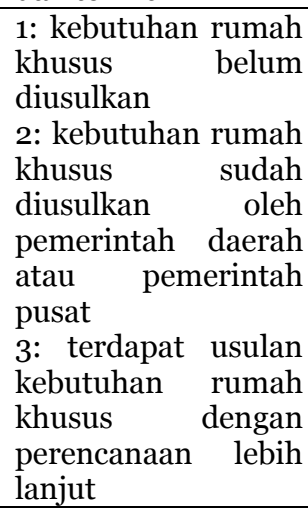 \\
\hline 5 & $\begin{array}{l}\text { Kependudukan/ } \\
\text { Target } \\
\text { pengguna }\end{array}$ & $\begin{array}{l}\text { Jumlah } \\
\text { penduduk } \\
\text { memenuhi } \\
\text { standar } \\
\text { penyediaan } \\
\text { rumah khusus } \\
\text { dan tingkat } \\
\text { kepentingan } \\
\text { memiliki } \\
\text { rumah }\end{array}$ & $\begin{array}{l}\text { 1: tidak terdapat } \\
\text { penduduk yang } \\
\text { memenuhi kriteria } \\
\text { target pengguna } \\
\text { 2: terdapat target } \\
\text { pengguna tetapi } \\
\text { tidak membutuhkan } \\
\text { rumah khusus } \\
\text { 3: terdapat target } \\
\text { pengguna sesuai } \\
\text { standar } \\
\text { membutuhkan dan } \\
\text { rumah khusus }\end{array}$ \\
\hline
\end{tabular}




\begin{tabular}{|c|c|c|c|}
\hline No & Kriteria & $\begin{array}{c}\text { Definisi } \\
\text { Operasional }\end{array}$ & Indikator \\
\hline 6 & Aksesibilitas & $\begin{array}{l}\text { Keterjangkauan } \\
\text { lokasi terhadap } \\
\text { akses PSU dan } \\
\text { aktivitas } \\
\text { kegiatan utama }\end{array}$ & $\begin{array}{l}\text { 1: lokasi lahan tidak } \\
\text { terjangkau akses } \\
\text { PSU dan aktivitas } \\
\text { kegiatan utama } \\
\text { 2: lokasi lahan } \\
\text { terjangkau PSU } \\
\text { tetapi tidak } \\
\text { mendukung } \\
\text { aktivitas/kegiatan } \\
\text { 3: lokasi terjangkau } \\
\text { terhadap PSU dan } \\
\text { aktivitas utama } \\
\text { target pengguna }\end{array}$ \\
\hline
\end{tabular}

Sumber: Modivikasi

\section{HASIL DAN PEMBAHASAN}

Nelayan adalah setiap orang yang mata pencahariannya melakukan penangkapan ikan [4].

- Nelayan Kecil adalah Nelayan yang melakukan Penangkapan Ikan untuk memenuhi kebutuhan hidup sehari-hari, baik yang tidak menggunakan kapal penangkap Ikan maupun yang menggunakan kapal penangkap Ikan berukuran paling besar 10 (sepuluh) gros ton (GT).

- Nelayan Tradisional adalah Nelayan yang melakukan Penangkapan Ikan di perairan yang merupakan hak Perikanan tradisional yang telah dimanfaatkan secara turun-temurun sesuai dengan budaya dan kearifan lokal

- Penangkapan Ikan adalah kegiatan untuk memperoleh Ikan di perairan yang tidak dalam keadaan dibudidayakan dengan alat dan cara yang mengedepankan asas keberlanjutan dan kelestarian, termasuk kegiatan yang menggunakan kapal untuk memuat, mengangkut, menyimpan, mendinginkan, menangani, mengolah, dan/atau mengawetkannya

\section{Karakteristik Non Fisik Perumahan}

a. Harga Lahan

Karakteristik potensi pengembangan lokasi mencakup aspek kepemilikan lahan, harga lahan, sosial ekonomi, kependudukan, karakteristik target pengguna, aksesibilitas, dan fungsi kegiatan. Harga lahan di Kabupaten Banjar sebagai berikut.

Tabel 3.

Harga lahan di kecamatan sekitar kabupaten banjar

\begin{tabular}{lll}
\hline \multicolumn{1}{c}{$\begin{array}{c}\text { Keca } \\
\text { matan }\end{array}$} & \multicolumn{1}{c}{ Lokasi } & \multicolumn{1}{c}{$\begin{array}{c}\text { Harga Tanah } \\
\left(\mathbf{R p} / \mathbf{m}^{\mathbf{2}}\right)\end{array}$} \\
\hline Aluh-Aluh & Aluh-Aluh & $50.000-100.000$ \\
Gambut & Sub-urban & $50.000-100.000$ \\
& Pusat kota (Jl. A. & $6 \mathrm{jt}-9 \mathrm{jt}$ \\
& Yani) & \\
Martapura & Indera Sari & $800.000-850.000$ \\
& Jl. A. Yani & $6 \mathrm{jt}-8 \mathrm{jt}$ \\
Karang Intan & Sub-urban & $50.000-100.000$ \\
& Pusat kota & $700.000-750.000$ \\
\hline
\end{tabular}

Sumber: Hasil Survey, 2017

Harga lahan di sekitar Kabupaten Banjar mencapai $\mathrm{Rp} 9$ juta per $\mathrm{m}^{2}$ khususnya pada wilayah pusat perkotaan. Kawasan di koridor jalan A. Yani merupakan wilayah dengan harga lahan tertinggi.
Hal inier disebabkan koridor jalan tersebut merupakan lokasi yang cukup strategis sebagai pusat perdagangan dan jasa, rekreasi, hingga wisata. Pada kawasan pingggiran kota masih terdapat lahan dengan harga $<\mathrm{Rp} 100.000$.

b. Budaya Bermukim

Ditinjau dari segi budaya, orang Banjar ialah kelompok masyarakat yang paling banyak mendiami kawasan Kalimantan Selatan. Setelah hidup nomaden, orang-orang Banjar kemudian tinggal di atas perahu sekitar tahun 70-an. Kemudian, budaya bermukim berubah, yaitu dengan membangun rumah-rumah mereka di tepi siungai atau tidak jauh dari sungai. Budaya bermukim ini terus berubah sehingga pada masa kini, budaya bermukim di tepi sungai semakin ditinggalkan. Selain desakan populasi, hal tersebut dipengaruhi oleh kebijakan Pemerintah Belanda yang memaksa penduduk tepi sungai berpindah ke tepi jalan beraspal.

Terdapat 11 tipe arsitektur rumah tradisional Banjar yang berkaitan erat dengan status sosial masyarakatnya, yaitu Bubungan Tinggi (Rumah Baanjung), Gajah Baliku, Gajah Manyusu, Balai Laki, Balai Bini, Palimasan, Palimbangan, Cacak Burung (Anjung Surung), Tadah Alas, Joglo, dan Lanting. Terdapat kesamaan yang menjadi ciri khas rumah tradisional Banjar, sebagai berikut [7].

a. Bangunan ditampilkan secara simetris / seimbang dengan garis pencerminan di bagian tengah. Kondisi simetris ini ditampilkan baik secara keseluruhan / sebagian facade bangunan.

b. Terdapat cukup banyak bukaan (khususnya jendela dan ventilasinya) yang dibuat dengan pola dan desain yang sangat dekoratif.

c. Pada bangunan dengan bentuk atap pelana terdapat dinding dengan ornamen atau angka pembangunannya.

d. Terdapat teras di bagian depan pintu utama.

e. Terdapat ruangan di sisi bangunan yang merupakan kamar tidur.

Tabel 4.

Jumlah keluarga menurut pentahapan keluarga sejahtera

\begin{tabular}{lrrr}
\hline Kecamatan & $\begin{array}{c}\text { Keluarga } \\
\text { Pra- } \\
\text { Sejahtera }\end{array}$ & $\begin{array}{c}\text { Keluarga } \\
\text { Sejahtera }\end{array}$ & Jumlah \\
\hline Aluh-Aluh & 1.635 & 6.6 .36 & 8.271 \\
Martapura & 2.689 & 17.727 & 20.416 \\
Gambut & 365 & 8.308 & 8.673 \\
Karang & 491 & 7.883 & 8.374 \\
Intan & $\mathbf{6 . 8 9 9}$ & $\mathbf{4 1 . 0 3 6}$ & $\mathbf{5 4 . 5 7 1}$ \\
\hline
\end{tabular}

Sumber: Kabupaten Banjar dalam Angka Tahun 2017

Pada tabel diketahui jumlah Keluarga PraSejahtera di Kabupaten Banjar cukup tinggi jika dibandingkan dengan jumlah pada wilayah kota. Jumlah Keluarga Pra-Sejahtera paling tinggi ialah di 
Kecamatan Martapura, yaitu 2.689 keluarga, dan Kecamatan Aluh-Aluh mencapai 1.635 keluarga. Sebanyak 19 desa di Kecamatan Aluh-Aluh termasuk ke dalam daerah terpencil. Desa-desa yang menjadi kampung nelayan pada umumnya tertinggal karena pembangunan infrastruktur yang minim. Terdapat Kampung Nelayan di Kecamatan Aluh-Aluh yang tersebar di Desa Simpang Warga Dalam, Labat Muara, Sungai Musang, Simpang Warga, Bakambat, dan Aluh-Aluh Besar. Jumlah rumah di Kampung Nelayan Kecamatan Simpang Warga Dalam tercatat sebanyak 90 unit.

Mayoritas warga Bakambat berprofesi sebagai nelayan tangkap. Infrastruktur di desa tersebut masih minim. Mayoritas warga bermukim di tepi muara Sungai Bartio, dimana rumah dibangun dengan kontruksi kayu. Berdasarkan Profil Desa Bakambat Tahun 2012, jumlah penduduk desa tersebut ialah 1.378 jiwa, meliputi 691 penduduk laki-laki dan 735 penduduk perempuan. Jumlah KK di desa tersebut sebanyak $395 \mathrm{KK}$.

Berdasarkan Profil Desa Labat Muara pada tahun 2012, data Sensus Penduduk menunjukkan jumlah penduduk di desa tersebut ialah 1.162 jiwa, terdiri dari 560 jiwa penduduk laki-laki dan 602 jiwa penduduk perempuan, serta 357 KK. Matapencaharian pokok penduduk desa tersebut berada di sektor pertanian dan perikanan tangkap. Desa Sungai Musang terletak di muara Sungai Barito yang berbatasan langsung dengan laut. Jumlah penduduk desa tersebut pada tahun 2016 ialah 1.609 jiwa. Jumlah penduduk di Aluh-Aluh Besar mencapai 3.617 jiwa.

Perkampungan nelayan di Desa Simpang Warga, Kecamatan Aluh-Aluh telah terhubung dengan jaringan jalan namun masih berupa tanah berpasir. Beberapa rumah penduduk dihubungkan dengan jembatan titian. Lebar jalan di kawasan ini sudah mencapai 6 meter tanpa saluran samping. Adapun jarak Kecamatan Aluh-Aluh dengan pusat Kabupaten Banjar (Martapura) ialah 39,2 Km. Kondisi aksesibilitas di lokasi alternatif kawasan rumah khusus nelayan dapat dilihat pada gambar berikut.

\section{Karakteristik Fisik Permukiman}

Persyaratan lokasi dan tanah pada program bantuan rumah khusus, yaitu [3]:

a. Lokasi harus sesuai dengan RTRW/RDTRK;

b. Tersedianya infrastruktur (jalan akses, air minum, dan listrik);

c. Luas minimal $1 \mathrm{Ha}$ atau 50 unit rumah mengelompok satu hamparan;

d. Jelas status hokum kepemilikan ha katas tanah (dengan bukti legalitas/sertifikat); dan

e. Tanah siap bangun.

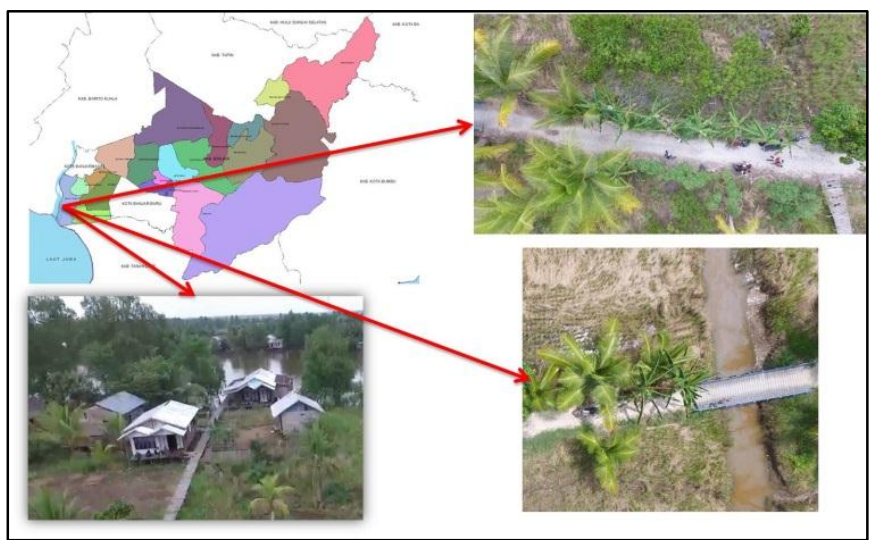

Gambar 1. Kondisi Aksesibilitas di Kawasan Rumah Nelayan Simpang Warga Dalam, Kabupaten Banjar

Kondisi jaringan jalan pada lokasi rumah nelayan disajikan pada tabel berikut.

Tabel 5.

Kondisi jaringan jalan menurut kecamatan

\begin{tabular}{ll}
\hline Kecamatan & \multicolumn{1}{c}{ Kondisi Jaringan Jalan } \\
\hline \multirow{3}{*}{ Gambut } & $\begin{array}{l}\text { Sebagian besar jalan sudah } \\
\text { diperkeras dengan aspal, namun } \\
\text { masih terdapat jalan kerikil } \\
\text { sepanjang 2,70 Km. }\end{array}$ \\
\hline Martapura & $\begin{array}{l}\text { Seluruh jaringan jalan telah } \\
\text { diaspal. }\end{array}$ \\
\hline Aluh-Aluh & $\begin{array}{l}\text { Panjang jalan diaspal ialah 10,70 } \\
\text { Km, jalan kerikil 14,20 Km, dan } \\
\text { jalan tanah 14,00 Km. }\end{array}$ \\
\hline \multirow{2}{*}{ Karang Intan } & $\begin{array}{l}\text { Sebagian besar jalan sudah } \\
\text { diperkeras dengan aspal, namun } \\
\text { masih terdapat jalan tanah } \\
\text { sepanjang 12,00 Km dan jalan } \\
\text { kerikil 1,oo Km. }\end{array}$ \\
\hline
\end{tabular}

Sumber: Kabupaten Banjar dalam Angka Tahun 2016 dan 2017

Pada lokasi alternatif Rumah Khusus Nelayan di Desa Simpang Warga, Kecamatan Aluh-Aluh, Kabupaten Banjar, jaringan jalan belum dilengkapi saluran samping. Saluran drainase lainnya merupakan saluran primer atau saluran drainase alami, yaitu sungai yang berada di sekitar kawasan tersebut.

Penyediaan air bersih perpipaan di Kabupaten Banjar disediakan oleh PDAM Intan Banjar. Ketersediaan air bersih di Kabupaten Banjar saat ini diperoleh dari sistem perpipaan dan non-perpipaan. Air baku PDAM di Kabupaten Banjar bersumber dari distribusi PDAM lainnya, irigasi Riam Kanan, sumur dalam, Sungai Martapura, Sungai Riam Kiwa, Karang Jawa, dan SMP. 

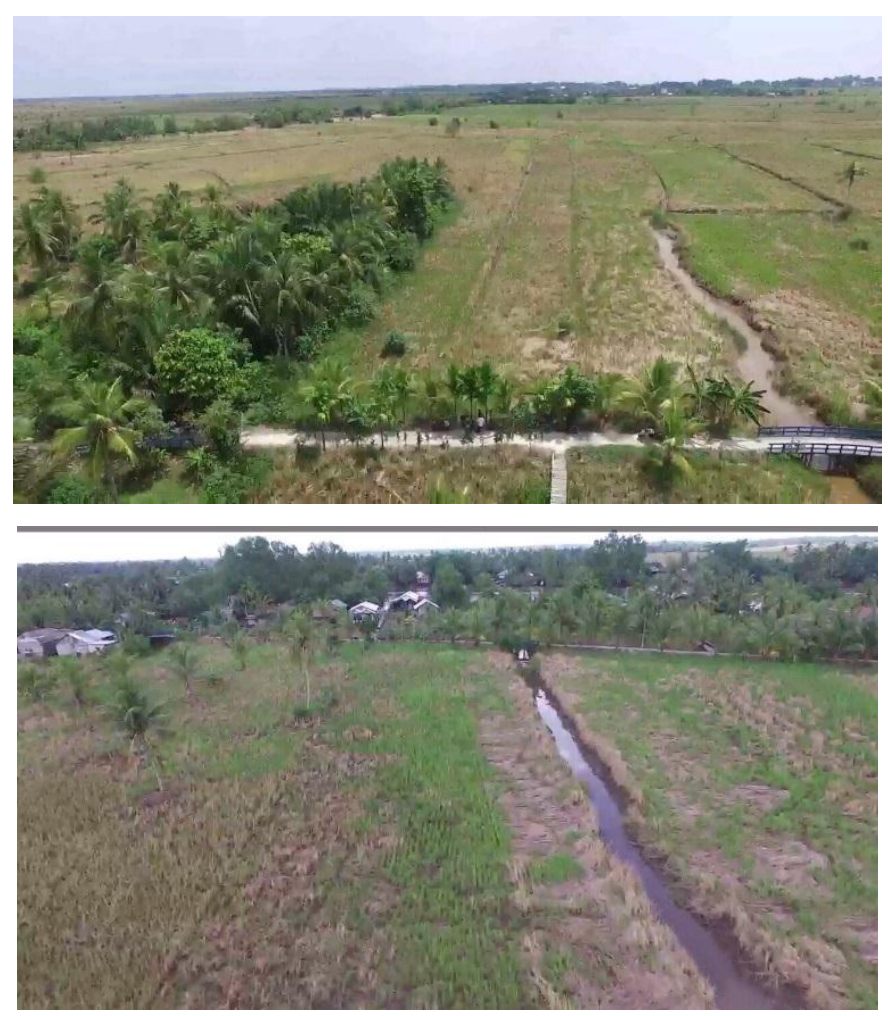

Gambar 2. Lokasi Potensial Rumah Nelayan di Kabupaten Banjar

\section{Analisa Kebijakan Perumahan}

Tempat tinggal dalam bentuk rumah merupakan salah satu kebutuhan dasar bagi manusia. Rumah disebut kebutuhan dasar karena merupakan unsur yang harus dipenuhi guna menjamin kelangsungan hidup manusia. Keberadaan rumah tinggal akan menentukan taraf kesejahteraan sekaligus kualitas hidup manusia itu sendiri karena itu suatu hunian pada hakekatnya dapat berpengaruh terhadap kualitas kehidupan orang-orang yang tinggal di dalamnya.

Tabel 6.

Analisa kebijakan terkait identifikasi rumah nelayan

\begin{tabular}{|c|c|c|c|}
\hline No & $\begin{array}{c}\text { Sumber } \\
\text { Dokumen }\end{array}$ & $\begin{array}{l}\text { Muatan } \\
\text { Kebijakan }\end{array}$ & $\begin{array}{c}\text { Implikasi } \\
\text { terhadap } \\
\text { pengemban } \\
\text { gan rumah } \\
\text { nelayan }\end{array}$ \\
\hline 1 & $\begin{array}{l}\text { Undang- } \\
\text { Undang } \\
\text { No 1 } \\
\text { Tahun } \\
2011 \\
\text { Tentang } \\
\text { Perumaha } \\
\text { n dan } \\
\text { Kawasan } \\
\text { Permukim } \\
\text { an }\end{array}$ & $\begin{array}{l}\text { - mengalokasikan } \\
\text { dana dan/atau } \\
\text { biaya } \\
\text { pembangunan } \\
\text { untuk } \\
\text { mendukung } \\
\text { terwujudnya } \\
\text { perumahan bagi } \\
\text { MBR; } \\
\text { - memfasilitasi } \\
\text { penyediaan } \\
\text { perumahan } \\
\text { dan kawasan } \\
\text { permukiman } \\
\text { bagi } \\
\text { masyarakat, } \\
\text { terutama bagi } \\
\text { MBR; dan } \\
\text { memfasilitasi } \\
\text { pelaksanaan } \\
\text { kebijakan dan } \\
\text { strategi pada }\end{array}$ & $\begin{array}{l}\text { Rumah } \\
\text { khusus dapat } \\
\text { diperuntukan } \\
\text { bagi nelayan } \\
\text { dengan } \\
\text { kriteria MBR } \\
\text { sesuai dengan } \\
\text { kebutuhan }\end{array}$ \\
\hline
\end{tabular}

\begin{tabular}{|c|c|c|c|}
\hline No & $\begin{array}{l}\text { Sumber } \\
\text { Dokumen }\end{array}$ & $\begin{array}{c}\text { Muatan } \\
\text { Kebijakan }\end{array}$ & $\begin{array}{c}\text { Implikasi } \\
\text { terhadap } \\
\text { pengemban } \\
\text { gan rumah } \\
\text { nelayan }\end{array}$ \\
\hline \multicolumn{4}{|c|}{$\begin{array}{l}\text { tingkat } \\
\text { provinsi }\end{array}$} \\
\hline 2 & $\begin{array}{l}\text { Peraturan } \\
\text { Pemerinta } \\
\text { h No. 14 } \\
\text { Tahun } \\
2016 \\
\text { tentang } \\
\text { Perumaha } \\
\text { n dan } \\
\text { Kawasan } \\
\text { Permukim } \\
\text { an }\end{array}$ & $\begin{array}{l}\text { - Mewujudkan } \\
\text { ketertiban } \\
\text { dalam } \\
\text { Penyelenggaraa } \\
\text { n Perumahan } \\
\text { dan Kawasan } \\
\text { Permukiman; } \\
\text { - Mewujudkan } \\
\text { keadilan bagi } \\
\text { seluruh } \\
\text { pemangku } \\
\text { kepentingan } \\
\text { terutama bagi } \\
\text { MBR dalam } \\
\text { Penyelengga- } \\
\text { raan Perumahan } \\
\text { dan Kawasan } \\
\text { Permukiman. } \\
\text { - Perumahan } \\
\text { mencakup } \\
\text { Rumah atau } \\
\text { Perumahan } \\
\text { beserta } \\
\text { Prasarana, } \\
\text { Sarana, dan } \\
\text { Utilitas Umum. } \\
\text { Rumah } \\
\text { sebagaimana } \\
\text { dimaksud } \\
\text { dibedakan } \\
\text { berdasarkan } \\
\text { pelaku } \\
\text { pembangunan } \\
\text { dan penghunian, } \\
\text { salah satunya } \\
\text { rumah khusus } \\
\text { yang layak huni } \\
\text { dengan tata } \\
\text { bangunan dan } \\
\text { lingkungan yang } \\
\text { terstruktur. } \\
\end{array}$ & $\begin{array}{l}\text { Penyediaan } \\
\text { rumah khusus } \\
\text { menjadi salah } \\
\text { satu sasaran } \\
\text { penyelenggara } \\
\text { an perumahan } \\
\text { dengan syarat } \\
\text { layak huni, } \\
\text { memenuhi } \\
\text { kebutuhan } \\
\text { rumah, dan } \\
\text { tata bangunan } \\
\text { dan } \\
\text { lingkungan } \\
\text { yang } \\
\text { terstruktur }\end{array}$ \\
\hline 3 & $\begin{array}{l}\text { Rencana } \\
\text { Pembangu } \\
\text { nan } \\
\text { Jangka } \\
\text { Menengah } \\
\text { Nasional } \\
\text { dan Nawa } \\
\text { Cita 2015- } \\
2019\end{array}$ & $\begin{array}{l}\text { Berdasarkan Nawa } \\
\text { cita nomor } 3 \text {, yaitu } \\
\text { "Membangun } \\
\text { Indonesia dari } \\
\text { pinggiran dengan } \\
\text { memperkuaat } \\
\text { daerah dalam } \\
\text { kerangka negara } \\
\text { kesatuan", } \\
\text { memiliki beberapa } \\
\text { arahan yaitu: } \\
\text { - Pemerataan } \\
\text { pembangunan } \\
\text { antara wilayah } \\
\text { terutama } \\
\text { kawasan timur, } \\
\text { dengan arahan } \\
\text { kebijakan } \\
\text { pembangunan } \\
\text { perkotaan: } \\
\checkmark \text { Percepatan } \\
\text { pemenuhan } \\
\text { standar } \\
\text { pelayanan } \\
\text { perkotaan } \\
\text { melalui } \\
\text { rumah layak } \\
\text { huni } \\
\checkmark \text { Pengembang } \\
\text { an } \\
\text { perumahan } \\
\text { sesuai } \\
\text { dengan } \\
\text { tipologinya }\end{array}$ & $\begin{array}{l}\text { Penyediaan } \\
\text { rumah khusus } \\
\text { harus } \\
\text { memenuhi } \\
\text { kelayakan } \\
\text { huni yang } \\
\text { disesuaikan } \\
\text { dengan } \\
\text { tipologi } \\
\text { wilayah. Salah } \\
\text { satu sasaran } \\
\text { penerima } \\
\text { rumah khusus } \\
\text { adalah } \\
\text { penduduk } \\
\text { rentan, } \\
\text { pekerja sosial, } \\
\text { disabilitas, } \\
\text { dan lansia. }\end{array}$ \\
\hline
\end{tabular}




\begin{tabular}{|c|c|c|c|c|c|c|c|}
\hline No & $\begin{array}{c}\text { Sumber } \\
\text { Dokumen }\end{array}$ & $\begin{array}{l}\text { Muatan } \\
\text { Kebijakan }\end{array}$ & $\begin{array}{c}\text { Implikasi } \\
\text { terhadap } \\
\text { pengemban } \\
\text { gan rumah } \\
\text { nelayan }\end{array}$ & No & $\begin{array}{c}\text { Sumber } \\
\text { Dokumen }\end{array}$ & $\begin{array}{l}\text { Muatan } \\
\text { Kebijakan }\end{array}$ & $\begin{array}{c}\text { Implikasi } \\
\text { terhadap } \\
\text { pengemban } \\
\text { gan rumah } \\
\text { nelayan }\end{array}$ \\
\hline & & $\begin{array}{l}\text { - Pengurangan } \\
\text { ketimpangan } \\
\text { antara kelompok } \\
\text { ekonomi } \\
\text { masyarakat: } \\
\checkmark \text { Menjamin } \\
\text { perlindunga } \\
\text { n sosial bagi } \\
\text { penduduk } \\
\text { rentan dan } \\
\text { pekerja } \\
\text { informal } \\
\text { Meningkatk } \\
\text { an dan } \\
\text { memperluas } \\
\text { pelayanan } \\
\text { dasar bagi } \\
\text { penduduk } \\
\text { rentan dan } \\
\text { kurang } \\
\text { mampu, } \\
\text { termasuk } \\
\text { disabilitas } \\
\text { dan lansia. }\end{array}$ & & & & $\begin{array}{l}\text { bagi kelompok } \\
\text { masyarakat di } \\
\text { kawasan khusus } \\
\text { seluruh indonesia” } \\
\text { Sasaran strategis } \\
\text { dimaksudkan } \\
\text { untuk mencapai } \\
\text { tujuan diatas, } \\
\text { untuk itu dalam } \\
\text { rangka mencapai } \\
\text { sasaran strategis } \\
\text { Direktorat Khusus } \\
\text { 2015-2019 adalah } \\
\text { sebagai } \\
\text { berikut: } \\
\text { - Teridentifikasi } \\
\text { nya kawasan- } \\
\text { kawasan } \\
\text { rumah khusus } \\
\text { yang layak } \\
\text { huni } \\
\text { Pembangunan } \\
\text { rumah khusus }\end{array}$ & $\begin{array}{l}\text { negara } \\
\text { dalam } \\
\text { rangka } \\
\text { pemenuhan } \\
\text { kebutuhan } \\
\text { rumah bagi } \\
\text { kelompok } \\
\text { masyarakat } \\
\text { Rumah } \\
\text { khsusu } \\
\text { dapat } \\
\text { berupa } \\
\text { pembangun } \\
\text { an rumah } \\
\text { baru atau } \\
\text { rehabilitasi } \\
\text { bangunan } \\
\text { yang sudah } \\
\text { ada }\end{array}$ \\
\hline 4 & $\begin{array}{l}\text { Rencana } \\
\text { Strategis } \\
\text { Kementeri } \\
\text { an } \\
\text { Pekerjaan } \\
\text { Umum } \\
\text { dan } \\
\text { Perumaha } \\
\text { n Rakyat } \\
\text { 2015-2019 }\end{array}$ & $\begin{array}{l}\text { Arahan fasilitas } \\
\text { pembangunan } \\
\text { rumah khusus } \\
\text { sebanyak } 6.384 \\
\text { unit rumah khusus } \\
\text { di daerah pasca } \\
\text { bencana/konflik, } \\
\text { maritim dan } \\
\text { perbtasan negara } \\
\text { yang dilengkapi } \\
\text { dengan PSU } \\
\text { pendukung. }\end{array}$ & $\begin{array}{l}\text { Rumah } \\
\text { khusus belum } \\
\text { diprioritaskan } \\
\text { di } \\
\text { Kalimantan, } \\
\text { akan tetapi } \\
\text { arah } \\
\text { pengembanga } \\
\text { n adalah } \\
\text { rumah khsuus } \\
\text { di daerah } \\
\text { bencana/konfl } \\
\text { ik, nelayan, } \\
\text { maritim dan } \\
\text { perbatasan } \\
\text { dengan PSU } \\
\text { yang } \\
\text { mendukung }\end{array}$ & & & $\begin{array}{l}\text { yang layak } \\
\text { huni berupa } \\
\text { pembangunan } \\
\text { rumah baru } \\
\text { atau } \\
\text { rehabilitasi } \\
\text { bangunan } \\
\text { rumah yang } \\
\text { dilengkapi } \\
\text { dengan DED } \\
\text { Meningkatnya } \\
\text { pembangunan } \\
\text { Rumah } \\
\text { Khusus } \\
\text { sebanyak } \\
\text { 50.ooo unit } \\
\text { sampai } \\
\text { dengan Tahun }\end{array}$ & \\
\hline 5 & $\begin{array}{l}\text { Tema, } \\
\text { Arah } \\
\text { Kebijakan, } \\
\text { dan } \\
\text { Prioritas } \\
\text { Pembangu } \\
\text { nan RKP } \\
2017 \\
\text { Kementeri } \\
\text { an } \\
\text { Perencana } \\
\text { an } \\
\text { Pembangu } \\
\text { nan } \\
\text { nasional } \\
\end{array}$ & $\begin{array}{l}\text { Dimensi } \\
\text { Pembangunan } \\
\text { Manusia, salah } \\
\text { satunya terdiri } \\
\text { dari pembangunan } \\
\text { perumahan dan } \\
\text { permukiman } \\
\text { memiliki prioritas } \\
\text { berupa "fasilitasi } \\
\text { penyediaan hunian } \\
\text { baru dan } \\
\text { Prasarana, Sarana, } \\
\text { dan Utilitas (PSU) } \\
\text { Pendukung" }\end{array}$ & $\begin{array}{l}\text { Provinsi } \\
\text { Kalimantan } \\
\text { Selatan dapat } \\
\text { mengisi } \\
\text { bagian dari } \\
\text { target 50.ooo } \\
\text { rumah khusus } \\
\text { yang } \\
\text { diarahkan } \\
\text { untuk } \\
\text { bencana dan } \\
\text { MBR dalam } \\
\text { arti luas }\end{array}$ & & & $\begin{array}{l}2019 \\
\text { mencakup } \\
\text { rumah khusus } \\
\text { untuk nelayan, } \\
\text { kawasan } \\
\text { perbatasan, } \\
\text { rumah pasca } \\
\text { bencana dan } \\
\text { rumah khusus } \\
\text { untuk daerah } \\
\text { terpencil dan } \\
\text { daerah } \\
\text { tertinggal } \\
\text { Bekerjasama } \\
\text { dengan }\end{array}$ & \\
\hline 6 & $\begin{array}{l}\text { Rencana } \\
\text { Strategis } \\
\text { Direktorat } \\
\text { Rumah }\end{array}$ & $\begin{array}{l}\text { visi Direktorat } \\
\text { Rumah Khusus } \\
\text { tahun 2015-2019 } \\
\text { adalah }\end{array}$ & $\begin{array}{ll} & \text { Sasaran } \\
\text { rumah } \\
\text { khusus } \\
\text { diarahkan }\end{array}$ & & & $\begin{array}{l}\text { pemerintah } \\
\text { daerah dalam } \\
\text { pembangunan } \\
\text { rumah khusus }\end{array}$ & \\
\hline & $\begin{array}{l}\text { Khusus } \\
\text { Kementeri } \\
\text { an } \\
\text { Pekerjaan } \\
\text { Umum } \\
\text { dan } \\
\text { Perumaha } \\
\text { n Rakyat }\end{array}$ & $\begin{array}{l}\text { "terwujudnya } \\
\text { penyediaan } \\
\text { perumahan khusus } \\
\text { bagi daerah pasca } \\
\text { bencana/konflik, } \\
\text { maritim, pulau } \\
\text { terluar, daerah } \\
\text { terpencil, daerah } \\
\text { yang terkena } \\
\text { dampak } \\
\text { pembangunan dan } \\
\text { perbatasan negara } \\
\text { dalam } \\
\text { rangka } \\
\text { pemenuhan } \\
\text { kebutuhan rumah }\end{array}$ & $\begin{array}{l}\text { bagi } \\
\text { kawasan } \\
\text { pasca } \\
\text { bencana/ko } \\
\text { konflik, } \\
\text { maritim, } \\
\text { pulau } \\
\text { terluar, } \\
\text { daerah } \\
\text { terpencil, } \\
\text { daerah yang } \\
\text { terkena } \\
\text { dampak } \\
\text { pembangun } \\
\text { an dan } \\
\text { perbatasan }\end{array}$ & 7 & $\begin{array}{l}\text { Peraturan } \\
\text { Daerah } \\
\text { Provinsi } \\
\text { Kalimanta } \\
\text { n Selatan } \\
\text { No. 9 } \\
\text { Tahun } \\
2015 \\
\text { Tentang } \\
\text { RTRW } \\
\text { Provinsi } \\
\text { Kalimanta } \\
\text { n Selatan } \\
\text { Tahun } \\
\text { 2015-2035 }\end{array}$ & $\begin{array}{l}\text { Rencana } \\
\text { pengembangan } \\
\text { kawasan } \\
\text { peruntukan } \\
\text { permukiman } \\
\text { seluas kurang } \\
\text { lebih } 217.243 \\
\text { hektar tersebar di } \\
\text { Kota Banjarmasin, } \\
\text { Banjarbaru, } \\
\text { Kabupaten Banjar, } \\
\text { Barito Kuala, } \\
\text { Tapin, Hulu } \\
\text { Sungai Selatan, } \\
\text { Hulu Sungai } \\
\text { Tengah, Hulu }\end{array}$ & $\begin{array}{l}\text { Kawasan yang } \\
\text { diarahkan } \\
\text { sebagai } \\
\text { peruntukan } \\
\text { permukiman } \\
\text { adalah Kota } \\
\text { Banjarbaru, } \\
\text { Kabupaten } \\
\text { Banjar, dan } \\
\text { Kabupaten } \\
\text { Tanah Laut }\end{array}$ \\
\hline
\end{tabular}




\begin{tabular}{|c|c|c|c|}
\hline No & $\begin{array}{l}\text { Sumber } \\
\text { Dokumen }\end{array}$ & $\underset{\text { Kebijakan }}{\text { Muatan }}$ & $\begin{array}{c}\text { Implikasi } \\
\text { terhadap } \\
\text { pengemban } \\
\text { gan rumah } \\
\text { nelayan } \\
\end{array}$ \\
\hline & & $\begin{array}{l}\text { Sungai Utara, } \\
\text { Tabalong, } \\
\text { Balangan, Tanah } \\
\text { laut, Tanah } \\
\text { Bumbu, dan } \\
\text { Kotabaru }\end{array}$ & \\
\hline
\end{tabular}

Terdapat kawasan pesisir di Kabupaten Banjar yang membutuhkan pemindahan lahan hunian dari yang kurang layak ke hunian baru yang dilengkapi infrastruktur permukiman, air bersih, drainase, sanitasi dan persampahan. Penyediaan rumah diarahkan pada lahan-lahan baru di luar kawasan permukiman nelayan yang sudah ada.

Tabel 8.

Skoring alternatif kriteria Potensi rumah khusus

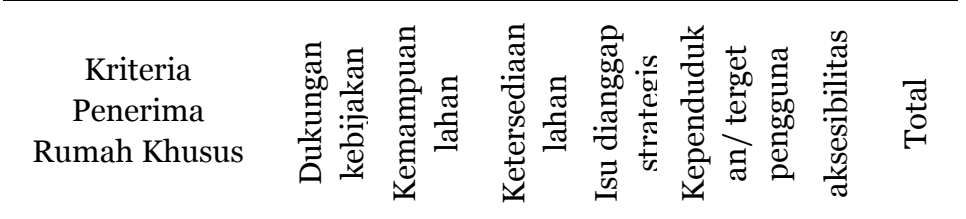

\begin{tabular}{|c|c|c|c|c|c|c|c|}
\hline $\begin{array}{l}\text { Masyarakat di } \\
\text { perbatasan } \\
\text { wilayah/ negara }\end{array}$ & 1 & 3 & 1 & 1 & 1 & 1 & 8 \\
\hline $\begin{array}{l}\text { Prajurit } \\
\text { dan/atau } \\
\text { petugas negara }\end{array}$ & 1 & 3 & 1 & 1 & 1 & 1 & 8 \\
\hline $\begin{array}{l}\text { Masyarakat } \\
\text { nelayan }\end{array}$ & 3 & 3 & 3 & 3 & 3 & 2 & 17 \\
\hline $\begin{array}{l}\text { Masyarakat } \\
\text { yang terkena } \\
\text { program } \\
\text { pembangunan } \\
\text { pemerintah }\end{array}$ & 1 & 3 & 1 & 1 & 1 & 1 & 8 \\
\hline $\begin{array}{l}\text { Korban bencana } \\
\text { alam }\end{array}$ & 2 & 3 & 1 & 2 & 2 & 1 & 11 \\
\hline $\begin{array}{l}\text { Masyarakat } \\
\text { yang bertempat } \\
\text { tinggal di pulau } \\
\text { terluar, terpencil } \\
\text { atau pedalaman }\end{array}$ & 1 & 3 & 1 & 1 & 1 & 1 & 8 \\
\hline $\begin{array}{l}\text { Masyarakat di } \\
\text { lokasi rawan } \\
\text { resiko sosial }\end{array}$ & 1 & 3 & 1 & 1 & 1 & 1 & 8 \\
\hline $\begin{array}{l}\text { Masyarakat } \\
\text { dalam wilayah } \\
\text { pengolah } \\
\text { sumber daya } \\
\text { alam }\end{array}$ & 1 & 1 & 1 & 1 & 1 & 1 & 6 \\
\hline Transmigran & 1 & 2 & 1 & 1 & 1 & 1 & 8 \\
\hline $\begin{array}{l}\text { Masyarakat } \\
\text { dalam kawasan } \\
\text { cagar budaya }\end{array}$ & 1 & 3 & 1 & 1 & 1 & 1 & 8 \\
\hline $\begin{array}{l}\text { Masyarakat } \\
\text { yang } \\
\text { memerlukan } \\
\text { penanganan } \\
\text { khusus }\end{array}$ & 3 & 3 & 1 & 1 & 1 & 1 & 10 \\
\hline
\end{tabular}

\begin{tabular}{|c|c|c|c|c|c|c|c|}
\hline $\begin{array}{c}\text { Kriteria } \\
\text { Penerima } \\
\text { Rumah Khusus }\end{array}$ & 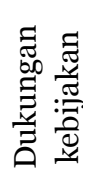 & 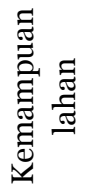 & 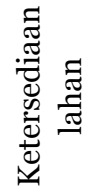 & 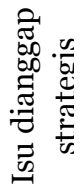 & 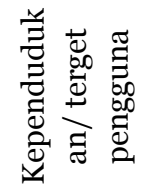 & 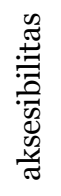 & 吾 \\
\hline $\begin{array}{l}\text { Masyarakat } \\
\text { khusus lainnya } \\
\text { (lanjut usia, } \\
\text { miskin, yatim } \\
\text { piatu, dan/ atau } \\
\text { anak terlantar) }\end{array}$ & 3 & 3 & 2 & 2 & 2 & 3 & 15 \\
\hline
\end{tabular}

Rumah nelayan di Kecamatan Aluh-Aluh dapat diprioritaskan sebagai rumah khusus di Kabupaten Banjar. Hal tersebut didasari atas nilai skor tertinggi berdasarkan analisa dukungan kebijakan tingkat nasional dan regional, kemampuan lahan yang sesuai, ketersediaan lahan yang masih luas, isu kebutuhan dukungan kegiatan maritim yang strategis, target pengguna yang jelas yaitu nelayan yang masih bergantung pada kegiatan penangkapan ikan, serta aksesibilitas yang baik. Rumah rumah di daerah permukiman nelayan dapat dibuat sederhana dan difungsikan secara optimal. Bentuk rumah juga sangat sesuai dengan kondisi lingkungan yang panas, dan lembab. Selain itu juga sesuai dengan budaya masyarakat. Bentuk rumah nelayan ddapat dipindah/diangkat tanpa merusak bangunan/konstruksi jika sitenya terkena kikisan ombak. Tersedia ruang untuk memenuhi aktivitas nelayan.

\section{SIMPULAN DAN SARAN}

Rumah nelayan sebagai salah satu jenis rumah khusus memiliki potensi yang besar untuk dikembangkan di Kabupaten Banjar, Kalimantan Selatan. Karakteristik fisik dan non fisik perumahan serta potensi pengembangannya telah sesuai dengan arahan kebijakan nasional, regional, dan lokal. Perumahan nelayan eksistng di Kecamatan Aluh-Aluh Kabupaten Banjar menepati prioritas utama berdasarkan kriteria yang telah ditetapkan. Pengembangan dilakukan pada lahan potensial yang ada dengan aksesibilitas yang baik menuju kawasan pesisir. Pengembangan juga diarahkan sesuai dengan karakteristik kearifan lokal rumah adat Banjar sehingga dapat menyesuaikandengan kondisi kemampuan lahan kawasan pesisir.

\section{UCAPAN TERIMA KASIH}

Tim penulis mengucapkan terima kasih kepada Dinas Perumahan dan Kawasan Permukiman Provinsi Kalimantan Selatan. 


\section{DAFTAR RUJUKAN}

\section{Buku}

[1] Rencana Pembangunan Jangka Menengah Nasional (RPJMN) 2014-2019

[2] Peraturan Menteru Perumahan Rakyat Nomor 10 Tahun 2013 Tentang Pedoman Bantuan Pembangunan Rumah Khusus

[3] Undang-Undang Republik Indonesia Nomor 1 Tahun 2011 Tentang Perumahan dan Kawasan Permukiman

[4] Undang-Undang Republik Indonesia Nomor 7 Tahun 2016 Tentang Perlindungan dan Pemberdayaan Nelayan, Pembudi Daya Ikan, dan Petambak Garam

\section{Jurnal}

[5] Ristianti, Novia Sari "Pengembangan Monsep Wisata Apung Kampung Nelayan Pesisir Balikpapan”, Jurnal Ruang, Vol 1, No. 1, h. 31-40, 2015.

[6] A'yun, Qurrotul "Evaluasi Tingkat Kualitas Hidup dengan Kriteria Eco Setllement pada Permukiman Nelayan di Desa Pesisir Tambak Wedi". EMARA Indonesian Journal of Architecture, Vol 2, No 2, h. 69-77, Desember 2016

[7] Hartatik "Eksistensi Rumah-Rumah Adat Banjar dalam Pembangunan Berkelanjutan". Balai Arkeologi Kalimantan Selatan, Vol 10, No 2, h. 145-158, Oktober 2016 